\title{
DETERMINANTS OF ISLAMIC BANK NON-PERFORMING FINANCING BY FINANCING CONTRACT (CASE STUDY: BANK BRI SYARIAH PRIVATE COMPANY)
}

\author{
Moch. Hadi Santoso ${ }^{* 1}$, Hermanto Siregar ${ }^{* *}$, Dedi Budiman Hakim ${ }^{* *)}$, and Mulya E. Siregar $\left.{ }^{* * *}\right)$ \\ *) PT Bank BRIsyariah Tbk \\ Jl. Abdul Muis No. 2-4, Jakarta Pusat 10160 \\ **) Departement of Economics, Faculty of Economics and Management, Bogor Agricultural University \\ Jl. Agatis, Campus of IPB Darmaga Bogor 16680 \\ ${ }^{* * *)}$ PT Bank Syariah Mandiri \\ Wisma Mandiri I Jl. MH. Thamrin No. 5, Jakarta 10340
}

\begin{abstract}
This study integrates the determinant factors of external and internal factors that affect the Bank BRISyariah Non-Performing Financing (NPF) in the period of Quarter I 2010 to Quarter IV 2017 by using multiple regression analysis. The external variables themselves consist of Inflation Rate, Benchmark Interest Rate/BI Rate, Economic Growth and USD/IDR Exchange Rate while internal factors consist of Return on Assets (ROA), Net Income Margin (NIM), Growth Financing, Financing to Deposit Ratio (FDR), Bank Rating (consisting of Good Corporate Governance, Risk Profile, Profitability and Capital) and NPF Management/NPF handling. Based on this methodology, the results with multiple regression analysis indicate that under existing contracts or financing contracts, the influencing factors are that 1) NPF in murabahah contract is influenced by bank rating - good corporate governance, exchange rate and benchmark interest rate; 2) NPF in ishtisna contract is influenced by bank rating - risk profile, bank rating - good corporate governance, NPF handling and inflation rate; 3) NPF in qardh contract is influenced by bank rating - rentability; 4) NPF in mudharabah/musyarakah contract is influenced by the rate of inflation; 5) NPF in ijarah contract is influenced by bank rating - risk profile, bank rating - good corporate governance, bank rating - rentability, financing growth and inflation rate. This research produces external and internal factors that need to get attention in order to handle non-performing financing based on financing contract better.
\end{abstract}

Keywords: non-performing financing, sharia bank, external factors, internal factors, financing contract

\begin{abstract}
Abstrak: Penelitian ini mengintegrasikan faktor-faktor penentu berupa faktor eksternal dan internal yang mempengaruhi Non-performing financing (NPF) Bank BRISyariah pada periode Triwulan I 2010 hingga Triwulan IV 2017 dengan menggunakan analisis regresi berganda. Variabel eksternal terdiri dari Tingkat Inflasi, Suku Bunga Benchmark / BI Rate, Pertumbuhan Ekonomi dan Nilai Tukar USD / IDR. Sedangkan faktor internal terdiri dari Return on Asset (ROA), Net Income Margin (NIM), Pembiayaan Pertumbuhan, Financing to Deposit Ratio (FDR), Tingkat Kesehatan Bank (terdiri dari Tata Kelola Perusahaan yang Baik, Profil Risiko, Profitabilitas dan Modal) dan Manajemen NPF / Penanganan NPF. Berdasarkan metodologi ini, hasil dengan analisis regresi berganda menunjukkan bahwa berdasarkan akad pembiayaan faktor-faktor yang mempengaruhi non-performing financing adalah 1) NPF pada akad murabahah dipengaruhi oleh tingkat kesehatan bank - tata kelola perusahaan yang baik, nilai tukar dan suku bunga acuan; 2) NPF pada akad ishtisna dipengaruhi oleh tingkat kesehatan bank - profil risiko, peringkat bank - tata kelola perusahaan yang baik, penanganan NPF dan tingkat inflasi; 3) NPF pada akad qardh dipengaruhi oleh tingkat kesehatan bank - rentabilitas; 4) NPF pada akad mudharabah / musyarakah dipengaruhi oleh tingkat inflasi; 5) NPF pada akad ijarah dipengaruhi oleh tingkat kesehatan bank - profil risiko, tingkat kesehatan bank - tata kelola perusahaan yang baik, tingkat kesehatan bank - rentabilitas, pertumbuhan pembiayaan, dan tingkat inflasi. Penelitian ini menghasilkan faktor eksternal dan internal yang perlu mendapat perhatian agar penanganan pembiayaan bermasalah berdasarkan kontrak pembiayaan menjadi lebih baik.
\end{abstract}

Kata kunci: non performing financing, bank syariah, faktor eksternal, faktor internal, akad pembiayaan

${ }^{1}$ Corresponding author:

Email: santosohadi57@gmail.com 


\section{INTRODUCTION}

Sharia banking as one preferred banking system in Indonesia has a very promising growth potential in the future. Indonesia is a country that has the largest number of Muslims in the world where more than $80 \%$ of the composition of people in Indonesia are Muslims (Antonio, 2001). The growth potential of sharia banking has shown its development since the establishment of Bank Muamalat in 1991, and there have been thirteen Sharia Commercial Banks since that year. Islamic banking had a 33.7\% Compounded Annual Growth Rate (CAGR) from 2006 to 2014. This growth was relatively much higher than that of the conventional Indonesian banking with CAGR of $16.2 \%$ in the same period. The comparison of the development of sharia banking to conventional banking in Indonesia during the period 2014 to 2016 can be seen in Table 1.

Sharia banking, which is part of the national banking, is also not spared from the impact of declining economic conditions both regionally and nationally. This can be seen in Table 1 indicating that there is indeed a slow growth in financing for national sharia banking. Evidently, the trend shows a decline in financing growth that only reached $6.09 \%$ in the middle of 2017 . The low growth of financing in 2017 was compared with that in 2016, showing a decline in the growth of sharia banking assets. The declining growth of Islamic banking assets contributes to the increase in Return on Assets in sharia banking as can be seen in Table 2. The trend value Return on Asset ratio increased from $0.63 \%$ in 2016 to $1.10 \%$ in June of 2017.

Along with the declining growth of asset, financing, DPK and profit of sharia banking nationally, it can also be seen that sharia banking has increased nonperforming financing (NPF). The NPF increase was quite high in the period of 2013 from $2.62 \%$ to $4.95 \%$ in 2014. In June 2017 position, sharia banking NPF was still quite high at $4.47 \%$. This is due to the slowing down of economic conditions due to the decline in commodity prices from 2015 to 2016, which resulted in an increase in NPF in sharia banking.

Table 1. Bank industries development in Indonesia (in Miliar Rupiah)

\begin{tabular}{|c|c|c|c|c|c|c|}
\hline $\begin{array}{l}\text { National } \\
\text { Banking }\end{array}$ & Des 14 & Des 15 & Des 16 & $\begin{array}{l}\text { Growth } \\
\text { Des15-Des } 16\end{array}$ & Juni 17 & $\begin{array}{l}\text { Growth } \\
\text { Des16-Juni17 }\end{array}$ \\
\hline Asset & $5,615,150$ & $6,095,908$ & $6,729,799$ & $10.40 \%$ & $7,025,811$ & $4.40 \%$ \\
\hline Financing & $5,468,910$ & $5,952,279$ & $6,570,903$ & $10.39 \%$ & $6,783,689$ & $3.24 \%$ \\
\hline Third-Party Funds & $4,594,876$ & $4,909,707$ & $5,399,210$ & $9.97 \%$ & $5,650,589$ & $4.66 \%$ \\
\hline Earning After Tax & 144,591 & 133,521 & 137,467 & $2.96 \%$ & 82,877 & \\
\hline Shariah Banking & Des 14 & Des 15 & Des 16 & $\begin{array}{l}\text { Growth } \\
\text { Des15-Des } 16\end{array}$ & Juni 17 & Growth \\
\hline \multicolumn{7}{|l|}{ Des16-Juni17 } \\
\hline Asset & 272,343 & 296,262 & 356,504 & $20.33 \%$ & 378,198 & $6.09 \%$ \\
\hline Financing & 199,330 & 212,996 & 248,007 & $16.44 \%$ & 265,317 & $6.98 \%$ \\
\hline Third-Party Funds & 217,858 & 231,175 & 279,335 & $20.83 \%$ & 302,013 & $8.12 \%$ \\
\hline Earning After Tax & 2,049 & 2,301 & 2,949 & $28.13 \%$ & 2,672 & \\
\hline
\end{tabular}

Table 2. Sharia Banking Financial Ratios (\%)

\begin{tabular}{ccccccccc}
\hline Tahun & 2011 & 2012 & 2013 & 2014 & 2015 & 2016 & Jun 2017 \\
\hline CAR & 16.63 & 14.13 & 14,42 & 15.74 & 15.02 & 16.63 & 16.42 \\
ROA & 1.79 & 2.14 & 2,00 & 0.41 & 0.49 & 0.63 & 1.10 \\
NPF & 2.52 & 2.22 & 2.62 & 4.95 & 4.84 & 4.42 & 4.47 \\
FDR & 88.94 & 100.00 & 100.32 & 86.66 & 88.03 & 85.99 & 82.69 \\
BOPO & 78.41 & 74.75 & 78.21 & 96.97 & 97.01 & 96.22 & 90.98 \\
\hline
\end{tabular}


Financing means the provision of monery or equivalent claims based on an agrement between the bank and other parties requiring the party financed to refund the money or the bill after a certain period of time in return or profit sharing. In Islamic Banks, non-performing financing frequently occured because of customers' default in committing their payment which caused loss of the Bank. According to Mahmoeddin (2004), non-performing financing attitude indications are determined by account attitudes, financial statement attitudes, business activities attitudes, customer attitudes and macro-economic attitudes. Furthermore, non-performing financing factors are driven by three elements that is the bank itself (creditor), debtors and other parties. From these perspectives, it can be concluded that many variables influence financing ratios or non-performing financing in financial institutions. Figure 1 below shows the Islamic Bank NPF movement and Nett NPF period from June 2014 to December 2016.
Bank BRISyariah as one part of Islamic banking is also experiencing the decline in its quality of financing, and that trend can be seen in Figure 2. It can be seen that Bank BRISyariah had the value of non-performing financing ratio above the average ratio of problematic financing of national sharia banking.

Some previous studies on the determinants of financing had only taken into account one factor or several factors related to internal factors or external factors affecting non-performing financing (Ogechi and Fredrick, 2017). There has never been a study of internal factors and external factors together. In addition to this, the novelty in this study is a study of the assessment of non-performing financing factors based on financing contracts. The other novelty in this study is the internal factor parameters used by the analysis of bank ratings based on risk or risk-based bank rankings as well as the use of short and long-term periods in the modeling analysis performed.

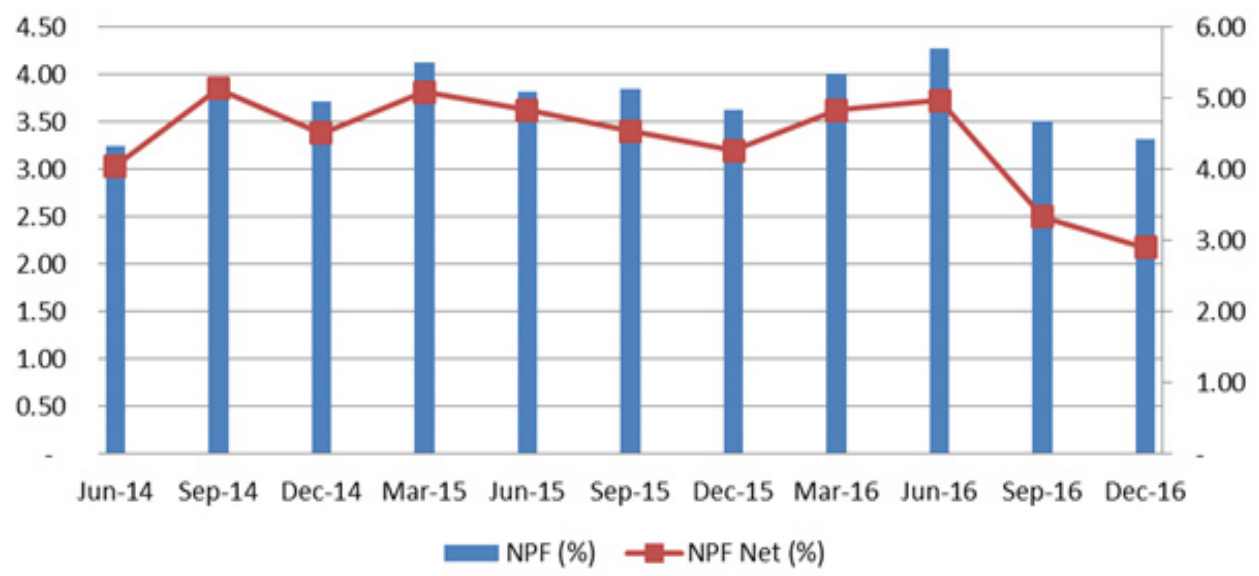

Figure 1. Islamic Bank NPF and Nett NPF trend in Indonesia (Financial Services Authority/FSA/OJK, 2017)

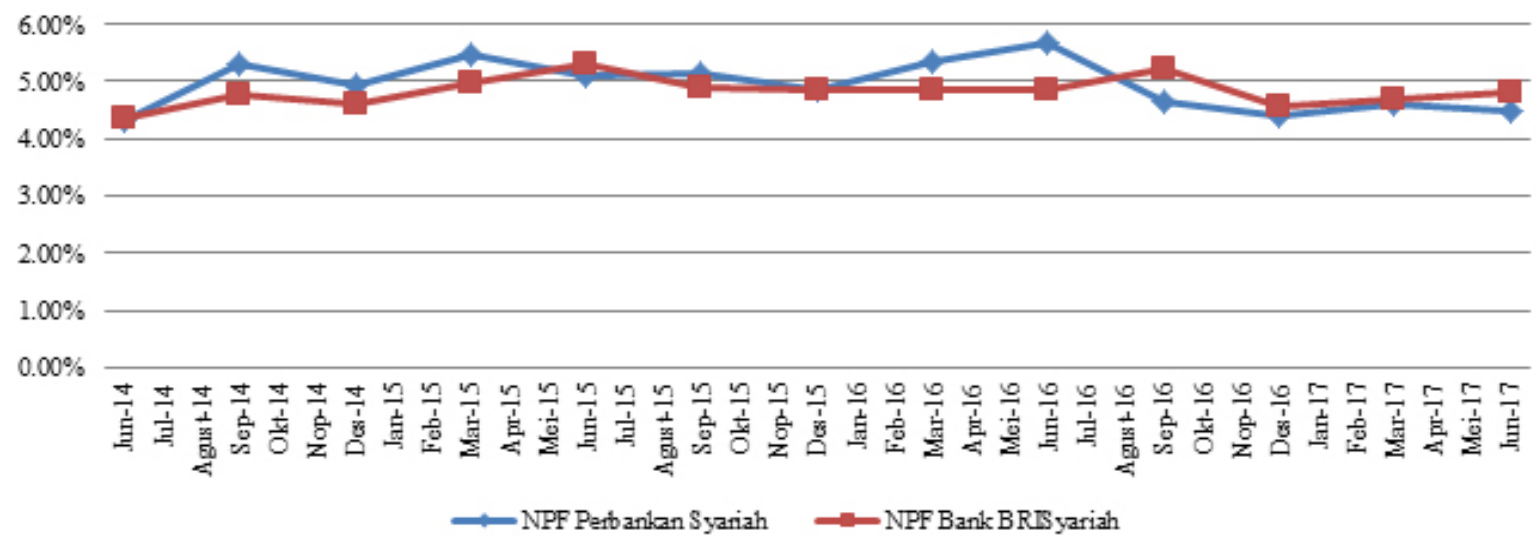

Figure 2. Islamic Bank NPF and Bank BRISyariah NPF Trend (Financial Services Authority/FSA/OJK, 2017) 
Much of the researches and analyses finding the internal and external factors influence financing qualitiesin Islamic Bank whether in Indonesia and several countries in Asia. Ikram et al. (2016), conducted empirical study was undertaken to explore the determinants of non-performing loans (NPLs) of small and medium enterprises (SMEs) sector held by the commercial banks with variable are branch age, duration of the loan, and credit policy were found to be significant determinants of NPLs. The study proposes that bankspecific and SME-specific microeconomic variables directly influence NPLs, while macroeconomic factors act as intermediary variables.

Likewise Indonesia Islamic Banking, Setiawan and Monita (2013) had conducted analysis on internal and external factors that influences Islamic Bank NPG during period 2007-2012. The result of significat internal factor influencing NPF is credibility of Management and the external factor is ROA. Havidz and Setiawan (2015) using four Islamic Bank as their research analysis sampling for period 2008-2014. Significantly factors that influenced four Islamic Bank NPF in Indonesia are company measurement, operational efficiency ratio, and GDP growth level. The internal and external factors of NPF specifically research conducted in Bank Victoria Syariah by Setiawan and Bhirawa (2016). Research showed that GDP growth factor, inflation and Capital Adequacy Ratio (CAR) has negative corellation and influenced significantly on NPD meanwhile exchange rate and operational efficiency ratio has positive corellation and significantly influence to Bank Victoria Syariah NPF.

In general, the research determinant of non-performing financing factor conducted only focused on one factor or some factors that come from internal factor or external factor only. The novelty in this study are the study of determinants of non-performing financing factors based on the financing contract, and one of the internal factor parameters used is the risk-based bank risk or risk based bank rating. Problem formulation research based on the above descriptives is how external and internal factors influenced Bank BRISyariah NPF based on type of contract financing from 2010 to 2017.

The research objectives are analysis on internal and external influences on Bank BRISyariah NPF based on financing contract consisting of 1) murabahah, 2) ishtisna, 3) qardh, 4) mudharabah/musyarakah, 5) ijarah, during the period of 2010-2017. The research design used the approach in determining factors that affect the problematic financing ratio in Bank BRISyariah per Financing Agreement. In this approach, Multiple Linear regression analysis was used to know the external factors and internal factors that had significant effects.

\section{METHODS}

The object of research was BRISyariah Bank. The number of research objects was chosen purposively based on the availability of data from the Financial Services Authority. This research was conducted from January 2018 to June 2018. The study was conducted in Jakarta using primary data and secondary data with the period of January 2010 to December 2017. The study was conducted using secondary data. The secondary data were used to analyze the factors that influence non-performing financing. The secondary data included data related to external and internal factors and nonperforming financing data based on business segments, economic sectors and contracts. They were also obtained through access to internal and external or third party data. The data were obtained from various sources such as the quarterly and annual financial statements of Bank BRISyariah, Bank Indonesia research institutions and the Financial Services Authority and other external sources. The secondary data used for research were from the period of January 2010 to December 2017 and processed using the Multiple Linear Regression analysis approach.

Data processing began with the calculation of several financial ratios for each independent variable and followed by the calculation of the analysis of Multiple Linear Regression (Abduh and Aizat, 2014). Before the analysis was carried out, a descriptive analysis was carried out to find out the distribution of data from each internal factor and external factor that affect the ratio of non-performing financing in BRISyariah Bank and used to develop company profiles that are descriptive statistics related to data collection and improvement and presentation of the results of the increase. Regression analysis stated the relationship among several characters were expressed in the form of non-independent variables as a function of the independent variables that influenced it. The goodness of multiple linear regression equations is to predict the magnitude of the quantitative influence of each independent variable if the influence of other variables is considered constant. 
The dependent variables used in this study was the results of non-performing financing (NPF) or the ratio of problematic financing of BRISyariah Bank. The independent variables used in analyzing factors that affect non-performing financing included Return On Assets (ROA), Net Operation Margin (NOM), Bank BRISyariah Financing Growth, Financing to Deposit Ratio (FDR), Non-performing financing Management (NPFM ), Bank Rating (including: Risk Profile, Good Corporate Governance, Rentability and Capital), Benchmark Interest Rate (7 days repo rate), Inflation, Rupiah exchange rate against dollar, and Economic growth.

The research framework of this study was developed from several previous studies related to the performance of Islamic commercial banks, handling of nonperforming financing, and financing contracts used by Islamic banks. Based on this research, the research framework was developed as shown in Figure 3. Based on the picture, it can be explained that the research was conducted to determine the factors that influence nonperforming financing based on financing agreements using multiple regression analysis.

\section{RESULTS}

\section{Multiple Regression Analysis}

The results of testing the correlation between the influence of internal factors and external factors on NPF in Bank BRISyariah based on financing contract by using multiple linear regression analysis are as follows:

Analysis of parameters that give a significant influence on financing quality based on murabahah BRISyariah financing scheme include Bank Rating for GCG (Good Corporate Governance), and Exchange Rate and Benchmark Interest Rate. The explanation of the significant parameters are as follows: For Bank Rating in GCG, it can be explained that an increase in GCG value of one unit will improve the quality of problem financing (NPF) by 0.099; For Exchange Rate (Rupiah Exchange Rate to US Dollar), it can be explained that an exchange rate increase by one unit will decrease the quality of problem financing (NPF) by 0.097 ; For Benchmark Interest Rate, it can be explained that an increase of Benchmark Interest Rate Value by one unit will improve the quality of problem financing (NPF) by 0.923 .

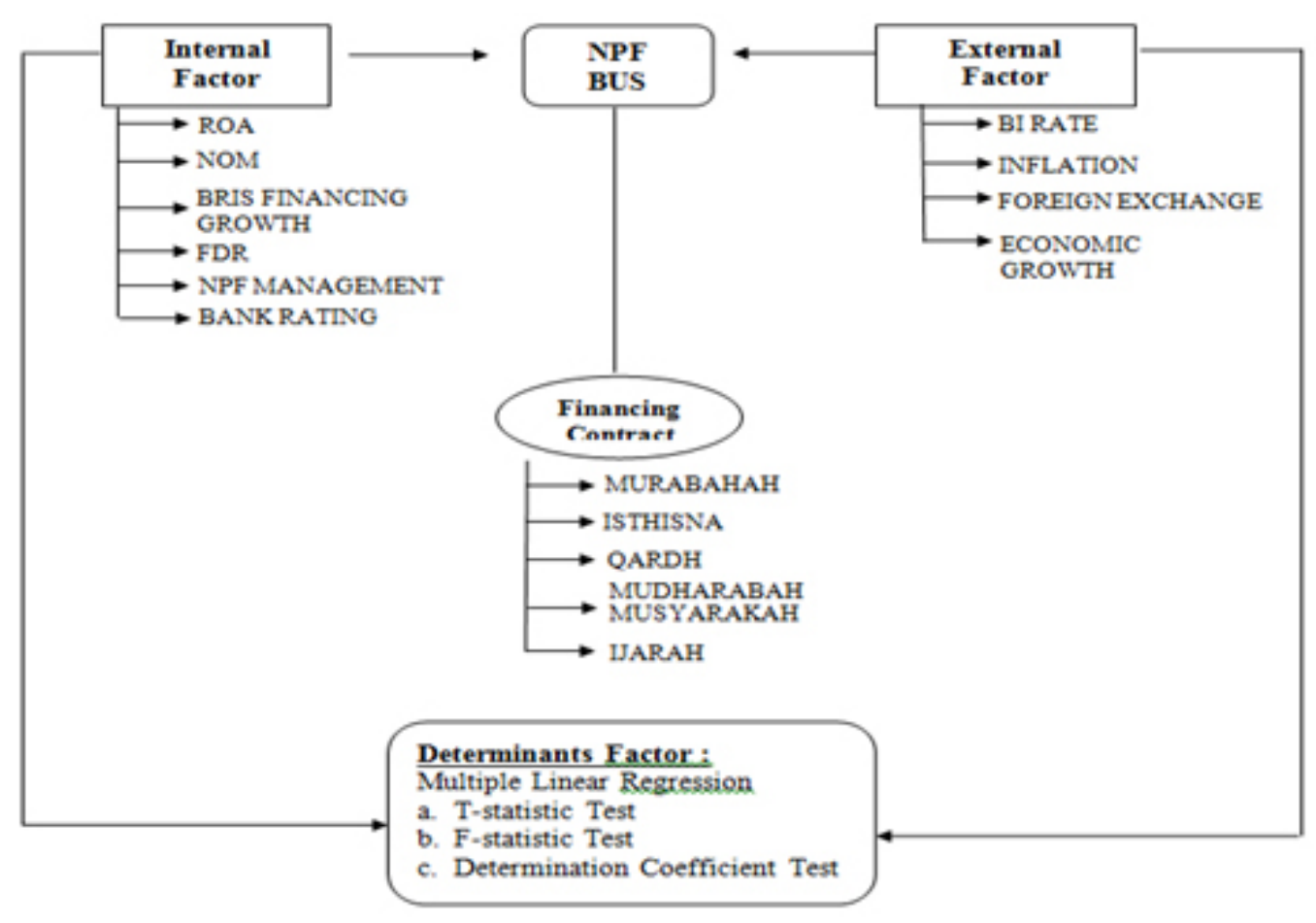

Figure 3. Research framework 
Based on the analysis result, the non-performing financing on several factors are presented. This is related to the financing model by using murabahah scheme (Fahrul, 2012). Where in this financing, contract is generally highly influenced by the determination of margin financed by Islamic banks. In determining the funding margin, generally, the exchange rate factor and benchmark interest rate greatly affect the decision taken by Islamic banks. At a time when the benchmark interest rate is high and exchange rate weakens, the specified margin will also be high; however, if the opposite happens, customers who have received financing cannot make changes to the margin; as a result, the ability to pay decrease.

The result of parameter analysis shows that the factors that give significant influence on financing quality based on financing contract ishtisna BRISyariah are Bank Rating for Risk Profile, Bank Rating for Good Corporate Governance, NPF Handling and Inflation Rate. The explanation of the significant parameters are as follows: For Bank Rating in Risk Profile, it can be explained that an increase of Risk Profile value by one unit will improve the quality of problem financing (NPF) by 0.158; For Bank Rating on GCG, it can be explained that an increase in GCG value by one unit will improve the quality of problem financing (NPF) of 1.862; For the handling of NPF, it can be explained that when done NPF handling since 2015 than before the handling of NPF until the end of 2014 have reduced the quality of problem financing (NPF) of 0.149 ; For Inflation Rate, it can be explained that an increase of Inflation Rate by one unit will improve the quality of problem financing (NPF) by 3.951.

Based on the financing scheme using the ishtisna contract, a financing concept with a gradual development model or pivot, it is influenced by risk appetite and good corporate governance policy. This is influential, because in the pattern of financing, ishtisna contract is strongly influenced by the ability of third parties in completing the desired work by bank customers and time of completion. If customer's work is completed in a relatively short time and in accordance with the agreemnet, the bank customers can directly operate and earn revenue. On the contrary, the customers will get a decrease in income and cannot fulfill their obligations to the sharia bank.
The parameter analysis result shows that the factor gives a significant influence on financing quality based on qardh financing contract in BRISyariah is Bank Rating for Rentability. The explanation of the significant parameters is as follows: For Bank Rating on Rentability, it can be explained that an increase in value of Rentability by one unit will increase the quality of problem financing (NPF) by 0.024 .

The parameter analysis show that the factor that gives a significant influence on financing quality based on mudharabah/musyarakah financing contract in BRISyariah is Inflation Rate. The explanation of the significant parameter is as follows: For Inflation Rate, it can be explained that when there is an increase of Inflation Rate by one unit, it will improve the quality of problem financing (NPF) by 0.383 .

Based on the scheme of financing by using mudharabah/ musyarakah contract in which the payment of liability is highly dependent on the customer income, it is strongly influenced by the inflation factor (Fahrul, 2012) and the inflation factor is used as a reference by sharia banking regulator in determining interest rate policy. Therefore, it can be indirectly said that inflation will affect the ability of customers in fulfilling their obligations to Islamic banks.

The parameter analysis shows that the factors that give significant influences on financing quality based on BRISyariah ijarah funding agreement include Bank Rating for Risk Profile, Bank Rating for GCG (Good Corporate Governance), Bank Rating for Rentability, Growth of Financing and Inflation Rate. The explanation of the significant parameters is as follows: For Bank Rating in Risk Profile, it can be explained that when an increase of Risk Profile value by one unit will improve the quality of problem financing (NPF) by 0.133 ; For Bank Rating on GCG, it can be explained that when an increase in GCG value by one unit will improve the quality of problem financing (NPF) by 1.886; For Bank Rating on Rentability, it can be explained that when an increase in value Rentability by one unit will increase the quality of problem financing (NPF) by 0.092 ; For Financing Growth, it can be explained when there is an increase in BRIS's Financing Growth by one unit, it will improve the quality of problem financing (NPF) by 0.346 ; For Inflation Rate, it can be explained that when there is an increase of Inflation Rate by one unit, it will increase the quality of problem financing (NPF) by 3,031 . 
Based on the financing scheme with ijarah contract in which the financing facility can be reviewed or changed, the ability to repay customer liabilities is also influenced by the value of inflation. An increase in interest rate due to rising inflation will affect the reduction of payment obligations by customers. In addition, the process of appraising prospective customers with the pattern of ijarah financing is influenced by risk appetite and process of GCG conducted by Islamic banks. This is because financing with ijarah agreement, the asset used as a rent object during the lease period still belongs to the bank; therefore, a risk assessment and strong corporate governance in every process of financing undertaken are necessary. The implementation process of risk assessment and corporate governance will result in customers to have a good ability in paying their loans.

\section{Value of Model Goodness}

For Goodness Value Model based on Multiple Linear Regression analysis, the results obtained are as follows:

Table value of coefficient of determination (R2/ R-Square) in Figure 4 shows that the model of regression equation is able to describe the actual condition of the existing population, with the value of the coefficient of determination of $66.8 \%$. This explains that the value of model goodness can be reasonably good because it is close to $70 \%$ as the minimum value of model goodness value. This means that the factors generated in the model are able to explain as a factor affecting the NPF based on murabahah scheme of $66.8 \%$, while the rest of $33.2 \%$ is explained by other factors.
Table value of coefficient of determination (R2/RSquare) in Figure 5 shows that the regression equation model has been able to describe the actual condition of the population equal to $81.4 \%$. This explains that the value of model goodness is highly good by yielding a value close to $100 \%$. This means that the factors generated in the model are able to explain the factors affecting the NPF based on ishtisna agreement by $81.4 \%$, while the remaining of $18.6 \%$ is explained by other factors.

Table value of coefficient of determination (R2/RSquare) in Figure 6 shows that the model of regression equation is able to describe the actual condition of the population is equal to $74.9 \%$. This explains that the value of model goodness is good enough because it has exceeded $70 \%$ as the minimum value of model goodness value. This means that the factors generated in the model are able to explain factors affecting the NPF based on qardh contract of $74.9 \%$, while the rest of $25.1 \%$ is explained by other factors.

Table value of coefficient of determination (R2/RSquare) in Figure 7 shows that the model of regression equation is able to describe the actual condition of the population by $57 \%$. This explains that the goodness of the model is not good enough because the value has not exceeded $70 \%$ as the minimum value of model goodness. This means that the factors generated in the model are able to explain factors affecting the NPF based on mudharabah/musyarakah agreement by $57 \%$, while the rest of $43 \%$ is explained by other factors.

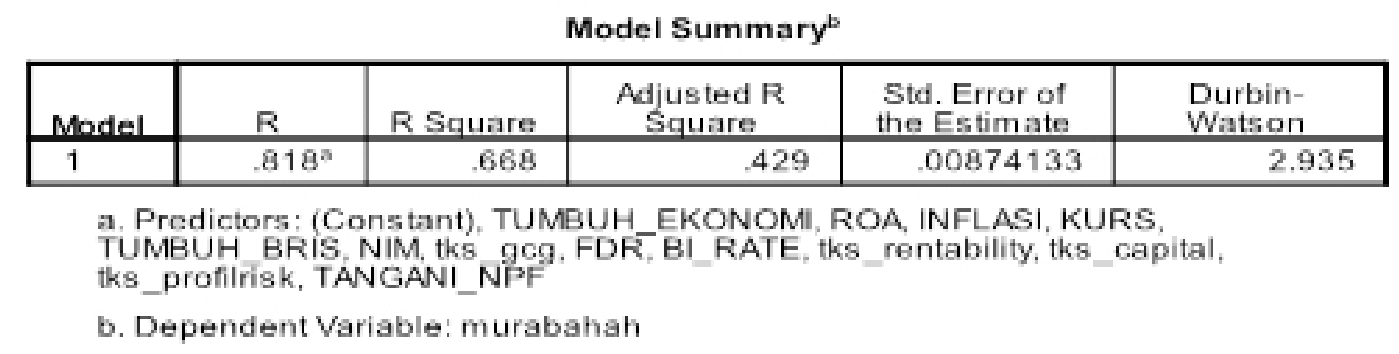

Figure 4. Value of cofficent of determination in murabahah contract 


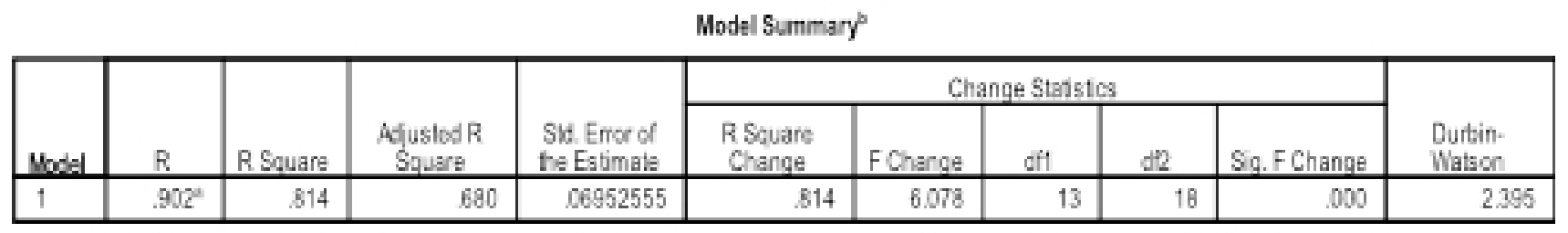

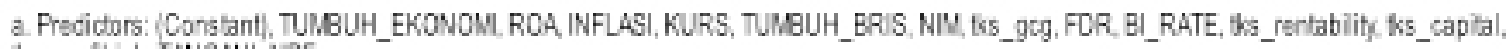
Ws_protirisk, TANGANI_NPF

b. Dependent Varable: ishosna

Figure 5. Value of coefficient of determination in ishtisna contract

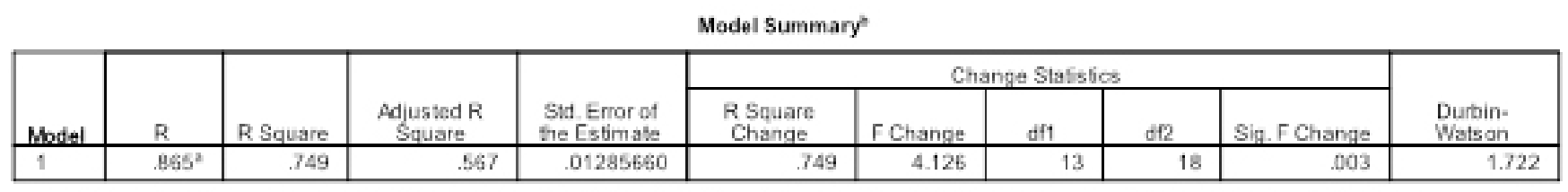

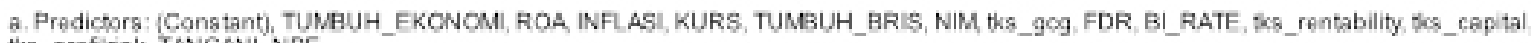
tiks_profilisk, TWNGWNINNPF

b. Dependent Variabie: qard

Figure 6. Value of coefficient of determination in qardh contract

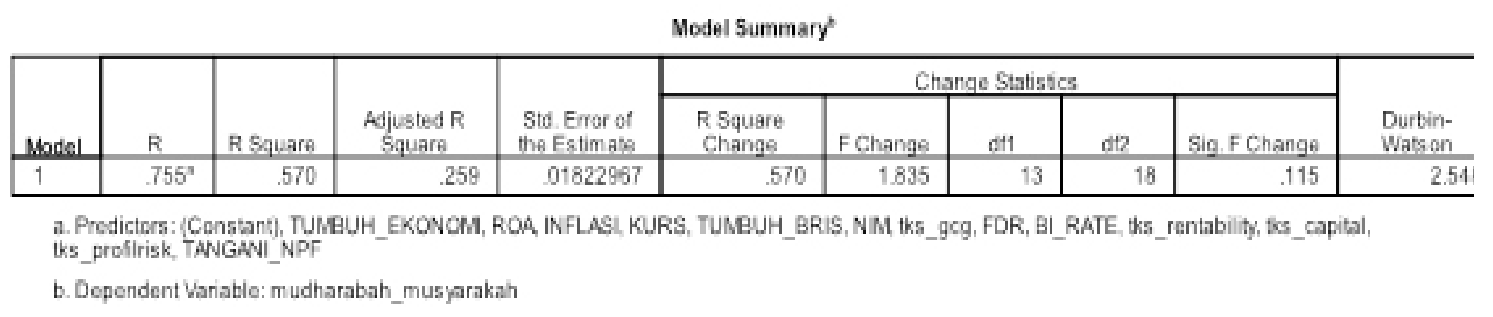

Figure 7. Value of coefficient of determination in mudharabah/musyarakah contract

Table value of coefficient of determination (R2/RSquare) in Figure 8 shows that the model of regression equation is able to describe the actual condition of the population by $87 \%$. This explains that the value of model goodness is very good by yielding a value close to $100 \%$. This means that the factors generated in the model are able to explain factors affecting the NPF based on ijarah agreement by $87 \%$, while the remaining $13 \%$ is explained by other factors.

\section{Managerial Implications}

The results of the analysis of internal and external factors that show that there are eight factors having significant effects on BRIFyariah NPF based on business segments. They consist of five internal factors: 1) Growth of Financing, 2) Management of NPF, 3)
Bank Soundness - Risk Profile, 4) Level Bank Health - Good Corporate Governance, 5) Bank Soundness Rentability and three external factors: 1) Inflation, 2) Exchange Rate, and 3) Benchmark Interest Rate. This condition shows that in general the causes of NPF based on financing contracts are highly influenced by bank internal factors. The financing contract that has a number of internal and external factors that have a significant effect on the occurrence of NPF is mostly found in the Ijarah financing agreement. As stated in the literature review referred to as the Ijarah contract, the contract for the provision of funds in order to transfer the usufructuary rights or benefits of an item or service is based on a lease transaction and it is not followed by the transfer of ownership of the goods themselves (Mutamimah and Chasanah, 2012). 


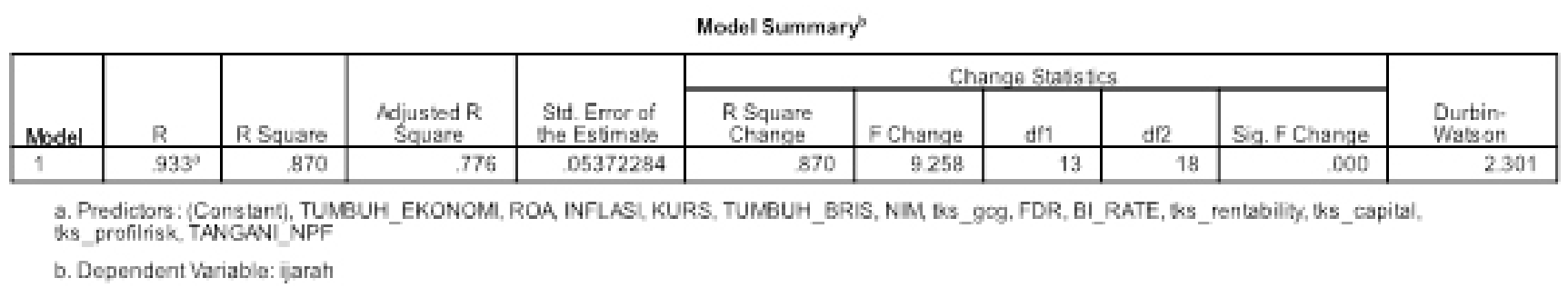

Figure 8. Value of coefficient of determination in ijarah contract

The development of financing with the Ijarah contract in BRISyariah shows growth from Rp719 billion in the second quarter of 2017 to Rp1.15 trillion at the end of the fourth quarter of 2017. This growth shows that financing with the Ijarah contract has high flexibility and suitability in meeting customer needs. Likewise, the quality of financing is currently well maintained with the NPF in the range of less than $1 \%$. As with the nature of the financing with the Ijarah contract, the reduction in NPF can be carried out by increasing financing growth using the Ijarah contract. This can be seen from the model produced in which growth of financing by one unit Ijarah contract will reduce the NPF by 0.35 units. However, carrying out the financing with the Ijarah contract needs to be carefully carried out. The results obtained provide a direction for Islamic banking to develop financing products constantly based on the Ijarah contract although the financing pattern with the Ijarah contract has an influence from external factors in the form of inflation. If inflation is higher, it will result in a decrease in the ability to pay from customers. This is because sharia commercial banks can review or evaluate rental fees charged to customers along with changes in inflation. The next factor that needs attention in financing with the Ijarah contract is good corporate governance. In this case, the process of analysis and evaluation of the customers must be carried out carefully, especially the suitability of the use of the Ijarah contract with the nature or characteristics of the customers. For regulators, the results of this study are increasingly reinforcing the managerial implications of increasing the function of supervision and monitoring of the implementation of good corporate governance in Islamic banking. Inflation is one thing that needs attention, because the results of this study, which states that inflation has a significant effect on the quality of financing, are in line with the research conducted by Firmansyah (2014) that inflation has a negative effect on problematic financing. Similarly, liquidity has a positive effect on problematic financing.

\section{CONCLUSIONS AND RECOMMENDATION}

\section{Conclusions}

The test results with multiple regression analysis show that there are several factors causing non-performing financing, depending on the financing contract. The influential factors are that 1) NPF in murabahah contract is influenced by bank rating - good corporate governance, exchange rate and benchmark interest rate; 2) NPF in ishtisna contract is influenced by bank rating - risk profile, bank rating - good corporate governance, NPF handling and inflation rate; 3) NPF in qardh contract is influenced by bank rating - rentability; 4) NPF in mudharabah/musyarakah contract is influenced by the rate of inflation; 5) NPF in ijarah contract is influenced by bank rating - risk profile, bank rating good corporate governance, bank rating - rentability, financing growth and inflation rate. In general, some results indicate that there is a strong influence between internal and external factors. This is in line with a number of researches previously conducted. However, this study found that each financing contract has different factors according to the scheme or model of the contract. Based on the results obtained in which factors affecting non-performing financing have been identifies, it is then necessary to establish a different management strategy/handling of NPF in accordance with each sector of the economy. All NPF management efforts should be formulated in strategy and regular monitoring.

\section{Recommendations}

Further research can be conducted to identify other external and internal factors that have an impact on problem financing. Conducting further research on economic growth actors who can become advocates for handling problem financing is also necessary. Further research on programs or activities can be carried out for handling problematic financing in accordance with 
developments in Islamic banking. Based on financing agreements for commercial business segments (murabahah, isthisna and ijarah), good corporate governance has an effect on NPF. Further research is required so that good corporate governance can play a role in the implementation of financing involving 3 (three) work units (financing pillars) i.e. business units, risk management units and operational/supporting units so that the NPF is expected to be more controlled.

\section{REFERENCES}

Abduh M, Aizat A. 2014. Factors determine Islamic banking performance in Malaysia: a multiple regression approach. Journal of Islamic Banking and Finance 31(1):44-54.

Antonio MS. 2001. Bank Syaríah dari Teori ke Praktek. Jakarta: Gema Insani Press.

Fahrul F. 2012. Pengaruh tingkat risiko pembiayaan musyarakah dan pembiayaan murabahah terhadap tingkat profitabilitas bank syariah. Jurnal Akuntansi PascaSarjana Universitas Syiah Kuala 2(1):76-85.

Firmansyah I. 2014. Determinant of non performing loan: The case of islamic bank in indonesia. Buletin Ekonomi Moneter dan Perbankan 17(2):233-247.

Havidz SAH, Setiawan C. 2015. Bank Bank efficiency and non-performing financing (NPF) in the indonesian islamic banks. Asian Journal of Economic Modelling 3(3): 61-79

Ikram A, Su Q, Ijaz F, Fiaz M. 2016. Determinants of non-performing loans : an empirical investigation of bank-specific microeconomics factors. The Journal of Applied Business Research 32(6): 1723- 1736.

Mahmoeddin. 2004. Tracking Non Performing Loans. Jakarta: Pustaka Sinar Harapan.

Mutamimah, Chasanah SNZ. 2012. Analisis eksternal dan internal dalam menentukan non performing financing bank umum syariah di indonesia. Jurnal Bisnis dan Ekonomi 19(1): 49-64.

[OJK] Otoritas Jasa Keuangan. 2017. Statistik Perbankan Syariah. Jakarta: OJK.

Ogechi A, Fredrick I. 2017. Macroeconomic determinants of non-performing loans in nigeria: an empirical analysis Journal of Developing Areas 51(2): 31-43.

Setiawan C, Bhirawa B. 2016. Non-performing financing (NPF) and cost efficiency of islamic banks in Indonesia period 2012Q1 to 2015Q2. Sixth Asia-Pacific Conference on Global Business, Economics, Finance and Sosial Science (AP16Thai Conference), Paper ID: T632.

Setiawan C, Monita EP. 2013. Non-performing financing and bank effiency of islamic banks in Indonesia. Journal of Islamic Finance and Business Research 2(1): 58-76. 